\title{
MORPHOLOGICAL AND ANATOMICAL MARKERS OF PHASE CHANGE TO ADULT STAGE IN OLIVE SEEDLINGS
}

(Received:11.12.2011)

\author{
By \\ E. S. Hegazi , A.A. Hegazi and A. M. Abd allatif \\ Pomology Department, Faculty of Agriculture, Cairo University, Giza, Egypt
}

\begin{abstract}
The current study was conducted during seasons 2009 to 2010 to investigate markers of phase change in olive seedlings. Three year old seedlings from open pollinated Koroneiki cv. seeds were used. Morphological and anatomical markers of phase change were measured in each seedling. Differences between the studied parameters were detected. The obtained results showed that the seedlings were divided into three groups (Juvenile, Intermediate-juvenile, Mature). In general, seedlings of the mature group recorded higher values of plant height, stem diameter, number of lateral shoots and internode length. Also while leaf length, width, area and L/D ratio were higher in the mature leaves. Leaf anatomy revealed that leaves of the adult seedlings had higher percentage of upper mesophyll, and additional layer of palisade mesophyll beside the lower epidermis. The studied characteristics could be used as preliminary markers to select seedlings of short juvenility in olive breeding programs.
\end{abstract}

Key words: juvenility, leaf anatomy, olive, phase change.

\section{INTRODUCTION}

Plants raised from seed germination enter a state of juvenility; during this stage the plant can not enter the flowering induction (Leopold and Kriedemann, 1975). The seedlings remained in juvenile stage for long period. In olive, the length of the juvenility period under natural conditions may last up to 15 years before transmission to the adult stage (Santos-Antunes et al., 2005).

One of the main objectives in olive breeding programs is the selection of new lines which begin fruiting in short period (Leon et al., 2007). Selection for the desired traits very early confers certain advantages for plant breeders because the sooner the screening of seedlings the more efficient the breeding programs (Pritsa et al., 2003). Also, the earliness of flowering is correlated with precocity and high productivity of the new line (Zimmerman, 1972).

There are progressive physiological, morphological, and anatomical changes associated with the passing from juvenility to maturity (Hackett and Murray, 1993; and Murray et al., 1994) which could be used as important markers of phase change (Basheer - Salimia et al., 2004).

The transmission from juvenility to adult stage in fruit tree is usually associated with attainment of certain plant size measured as shoot height ackett, 1985; and Poethig, 1990) and stem diameter (Santos-Antunes et al. 2005).

The differences between leaves in adult and juvenile seedlings of many species were documented, and were included in phenomenon called "Heteroblasty" (Allsopp, 1967). The heteroblasty consists of genetically programmed structural changes that occurs during the whole plant ontogeny and are linked to changes from juvenile to adult phase (Jones, 1999).

Moreno-Alias et al., (2009) reported that there was a significant difference between adult and juvenile leaves, leaf length, width, area and leaf length to width ratio consistently greater in the adult leaves.

Pritsa et al., (2003) reported that $74 \%$ of early flowering olive seedlings derived from the single branched seedling and only 26\% were from seedlings with lateral shoots. According to Lavee et al. (1996) the phase change from juvenile to adult stage in olive seedlings is associated with an increase in internode length. Moreno-Alias et al. (2009) reported that, in the transverse sections, total leaf thickness and thickness of both lower and upper mesophyll were higher in the adult than the juvenile leaves. As, the juvenile plant grows up structural differences along its stem may reflect the gradual change from juvenile to mature types 
of growth (Leopold and Kriedemann 1975). According to Hackett (1985) there is an over all spatial differences within the canopy in which the upper and peripheral parts of the plant mature while, the basal and inner parts remained juvenile.

The present study was designed to identify morphological and anatomical markers of phase change in olive seedling to assist selection of seedlings with short juvenility as early as possible.

\section{MATERIALS AND METHODS}

The present study was carried out during 2009 and 2010 seasons in a trial to investigate morphological and anatomical markers of phase change in olive seedlings. This study was conducted at the Nursery and Laboratory of Pomology Department, Faculty of Agriculture, Cairo University.

\subsection{Plant materials:}

The plant materials are consisted of 40 olive seedlings aged three years resulted from open pollination of $\mathrm{cv}$. "Koroneiki" The different morphological parameters i.e. plant height, stem diameter at $10 \mathrm{~cm}$ from soil surface, number of lateral shoots, internode length, leaf length and width were estimated, and leaf area $\left(\mathrm{cm}^{2}\right)$ was calculated using the following formula. Leaf Area $=0.53(\mathrm{~L} \times \mathrm{W})+1.66$ (Ahmed and Morsy, 1999), all the parameters were recorded during October of the two successive seasons (2009 and 2010).

To identify sites of phase change in the seedlings, each seedling was divided into 3 parts (basal, middle and terminal portion), internode length $(\mathrm{cm})$ and leaf area $\left(\mathrm{cm}^{2}\right)$ were recorded in each portion.

\subsection{Anatomy of olive leaves}

The anatomical studies were conducted on fully developed leaves from three sources:

Leaves of 8 month old olive plants cv. Koroneiki (derived from cuttings).

Leaves from olive seedlings that showed juvenile status.

Leaves from olive seedlings showed signs of transimition to adult stage.

The middle portion of leaf samples were fixed in mixture of F.A.A for $48 \mathrm{~h}$. The leaf samples were dehydrated through a series of ethyl and butyl alcohol and embedded in paraffin wax. The tissues were sectioned at $20 \mu \mathrm{m}$ with rotary microtome, mounted and stained with saffranin and light green. (Moreno-Alias et al., 2009). The leaf sections were examined under light microscope. Images were captured by Olympous BX.40 microscope supplement with video camera (Panasonic WV-CP 220, Japan).
The leaf mesophyll was divided into adaxial mesophyll (composed of the major palisade parenchyma I) and abaxial mesophyll, (composed of the spongy parenchyma) and palisade parenchyma II. (Moreno-Alias et al., 2009). Thickness of the different mesophyll types was measured using image analysis software and the percentage of adaxial to abaxial mesophyll was calculated.

\subsection{Experimental design and data analysis}

This study followed the complete randomized block design and data were subjected to analysis of variance (ANOVA) according to Snedecor and Cochran (1980) using MSTAT C statistical package (Freed et al., 1990) software, and means of the treatments were compared by Least Significant Difference (L.S.D) according to Duncan (1955) at significance level of 0.05 .

\section{RESULTS AND DISCUSSION \\ 3.1. Vegetative growth}

The obtained results indicated that there were obvious variations in all the morphological parameters, and the studied seedlings fill into 3 categories (Juvenile, Intermediate-juvenile, Mature), as described by (Pritsa et al., 2003 and Santos-Antunes et al., 2005).

\subsubsection{Seedling height}

It is clear from the data presented in Table (1) that there was an obvious difference in seedlings height during the two studied seasons. The studied seedlings fill in three groups according to seedling height. Seedling in the adult category including (Line 6, 7, 9, 11, 12, 13, 17, 19, 21, 22, 23, 25, 27, $29,33,38)$ recorded the highest values in both season (130.3 and $152.3 \mathrm{~cm}$, respectively), while seedlings in the $3^{\text {rd }}$ group recorded the lowest values (63.64 and $91.4 \mathrm{~cm}$, respectively), which including (Line 2, 3, 4, 5, 14, 18, 26, 36, 37, 39, 40).The Intermediate-juvenile seedlings including (Line1, 8,10,15,16,20,24,28,30,31,32,35).

According to Hackett (1985) the transmission from the juvenility to adult productive stage required the attainment of certain plant size measured as plant height. Kiran et al. (2008) used seedling height as a pre-selection criterion for the short juvenile stage in olive.

\subsubsection{Stem diameter}

The data in Table (1) show that seedlings of the mature group recorded the highest stem diameter category including (Line 6, 7, 9, 11, 12, $13,17,19,21,22,23,25,27,29,33,38)$, on the contrary, seedlings in the juvenility group recorded the lowest values (Line 2, 3, 4, 5, 14, 18, $26,36,37,39,40)$. The increase in stem diameter 
Table (1). Vegetative characteristics of seedlings with different developmental stages.

\begin{tabular}{|l|c|c|c|}
\hline \multicolumn{4}{|c|}{ Season 2009 } \\
\hline Seedling & $\begin{array}{c}\text { Plant height } \\
(\mathbf{c m})\end{array}$ & $\begin{array}{c}\text { Stem diameter } \\
(\mathbf{c m})\end{array}$ & No. lateral shoots \\
\hline Juvenile & $63.64 \mathrm{~b}$ & $0.53 \mathrm{c}$ & $8.05 \mathrm{~b}$ \\
\hline Intermediate-juvenile & $68.58 \mathrm{~b}$ & $0.61 \mathrm{~b}$ & $18 \mathrm{ab}$ \\
\hline Adult & $130.3 \mathrm{a}$ & $0.79 \mathrm{a}$ & $31.17 \mathrm{a}$ \\
\hline \multicolumn{4}{|c|}{ Season $\mathbf{2 0 1 0}$} \\
\hline Juvenile & $91.4 \mathrm{c}$ & $1.63 \mathrm{~b}$ & 27.31 \\
\hline Intermediate-juvenile & $120.5 \mathrm{~b}$ & $1.86 \mathrm{a}$ & 38.25 \\
\hline Adult & $152.3 \mathrm{a}$ & $1.92 \mathrm{a}$ & 45.82 \\
\hline
\end{tabular}

was correlated with the increase of seedling percentage in the adult stage (Santos-Antunes et al., 2005). According to Way (1971) apple with larger stem diameter come into flowering earlier than those with small diameter.

\subsubsection{Number of lateral shoot/seedling}

The data presented in Table (1) show a high difference between the seedlings in their ability to form lateral shoots.

Seedlings in the juvenility group (Line 2, 3, 4, $5,14,18,26,36,37,39$, and 40) produced the least number of lateral shoots in both studied seasons (8.05 and 27.3, respectively). While seedlings of the mature stage (Line 6, 7, 9, 11, 12, $13,17,19,21,22,23,25,27,29,33,38)$ produced the highest number (31.17 and 45.82). Number of lateral shoots and frequency forming shoots had an effect of the seedling ability to flower and can be used as a morphological trait for transmission to adult stage (Ligeng et al., 1995 and Pritsa et al., 2003).

\subsubsection{Leaf morphology}

As shown in Tables (2 and 3) a significant difference between leaves belonging to the different categories were found for the size parameter, leaf length width and area were greater for the adult seedlings compared with the juvenile seedlings while leaves from the $2^{\text {nd }}$ group had an intermediate values.

The differences in leaf measurements were more obvious in the second season compared with the first one.

Concerning the effect of site on leaf characteristics, it was obvious that the markers of phase change appeared on the terminal portion of the seedlings and it was more noticeable on the seedlings in the adult stage.
According to Zimmerman (1972) the leaf form change when it reached the maturity stage and this change occurs during the whole plant ontogeny and is linked to change from the juvenile stage to adult phase (Jones, 1999). Moreno-Alias et al. (2009) reported that there was a significant difference between adult and juvenile leaves, leaf length, width and area were higher in the adult leaves.

\subsubsection{Leaf shape}

Data in Table (3) indicate that leaves from the different categories were included in the elliptical shape $(\mathrm{L} / \mathrm{W}<4)$ and there were no significant differences between the leaves from the different categories during the $1^{\text {st }}$ season, while in the second season, leaves of the adult seedlings recorded the higher values compared with the seedling from the juvenile seedlings.

Also, the difference in shape index along the stem appeared only in the second season, and the $\mathrm{L} / \mathrm{W}$ ratio was higher in the upper portion of the seedlings. Lavee et al. (1996) noted an increase in $\mathrm{L} / \mathrm{W}$ ratio in the adult seedlings compared with juvenile seedlings. Also, Basheer-Salimia et al. (2004) reported that juvenile olive leaves were shorter and more rounded compared to the mature leaves.

\subsubsection{Internode length}

Internode length was significantly affected by seedling development stage and the site of measurement (Table, 4). Seedlings of the adult group recorded the highest internode length in both seasons compared with the other seedlings.

Also, the internode length was longer in the upper portion of the seedlings compared with the seedlings base . Lavee et al. (1996) reported that phase change from juvenility to adult stage in 


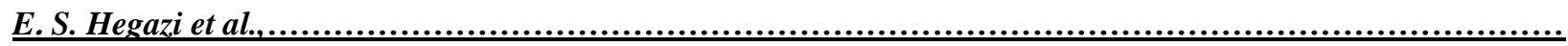

Table (2) : Leaf length and width of seedlings with different developmental stage.

\begin{tabular}{|c|c|c|c|c|c|c|}
\hline \multicolumn{7}{|c|}{ Season 2009} \\
\hline \multirow[t]{2}{*}{ Seedling } & \multicolumn{3}{|c|}{ leaf length $(\mathrm{cm})$} & \multicolumn{3}{|c|}{ leaf width $(\mathrm{cm})$} \\
\hline & Terminal & Mid. & Basal & Terminal & Mid. & basal \\
\hline Juvenile & $3.01 \mathrm{a}-\mathrm{c}$ & $2.42 \mathrm{~d}$ & $2.42 \mathrm{~d}$ & $1.04 a$ & - & $0.78 \mathrm{a}$ \\
\hline Transmission & $3.18 \mathrm{ab}$ & $2.7 \mathrm{~b}-\mathrm{d}$ & $2.56 \mathrm{~cd}$ & $1.04 a$ & $0.88 a$ & $0.79 \mathrm{a}$ \\
\hline Adult & $3.41 \mathrm{a}$ & $3.15 \mathrm{ab}$ & $2.63 \mathrm{~cd}$ & $1.03 a$ & $0.82 \mathrm{a}$ & $0.87 \mathbf{a}$ \\
\hline \multicolumn{7}{|c|}{ Season 2010} \\
\hline & Terminal & Mid. & Basal & Terminal & Mid. & Basal \\
\hline Juvenility & $2.86 \mathrm{~cd}$ & 2.73d & 2.73d & $1.05 b$ & - & 0.94c-e \\
\hline Transmission & $3.18 b$ & 2.68de & 2.68de & $1 \mathrm{~b}-\mathrm{d}$ & - & $0.87 \mathrm{e}$ \\
\hline Adult & $3.68 a$ & 3.06bc & $2.46 \mathrm{e}$ & $1.20 \mathrm{a}$ & $1.03 \mathrm{bc}$ & 0.91de \\
\hline
\end{tabular}

Table (3) : Leaf area and shape of seedling with different developmental stage.

\begin{tabular}{|c|c|c|c|c|c|c|}
\hline \multicolumn{7}{|c|}{ Season 2009} \\
\hline \multirow[t]{2}{*}{ Seedling } & \multicolumn{3}{|c|}{ leaf Area (cm) } & \multicolumn{3}{|c|}{ leaf shape index } \\
\hline & Terminal & Mid. & Basal & Terminal & Mid. & Basal \\
\hline Juvenile & 3.18a-c & - & $2.67 \mathrm{c}$ & $3.9 \mathrm{~b}$ & - & 3.13b \\
\hline Transmission & 3.16a-c & 3.12a-c & $2.75 \mathrm{bc}$ & 3.07b & $3.08 b$ & $3.24 \mathrm{~b}$ \\
\hline Adult & $3.54 \mathrm{a}$ & 3.35ab & $2.86 \mathrm{bc}$ & $3.29 \mathrm{~b}$ & $3.91 \mathrm{a}$ & $3.09 \mathrm{~b}$ \\
\hline \multicolumn{7}{|c|}{ Season 2010} \\
\hline & Terminal & Mid. & Basal & Terminal & Mid. & Basal \\
\hline Juvenile & $3.29 \mathrm{bc}$ & - & $3.01 \mathrm{~cd}$ & $2.07 b c$ & - & 2.95ab \\
\hline transmission & $3.39 \mathrm{~b}$ & - & 2.9d & $3.19 \mathrm{a}$ & - & 3.07a \\
\hline Adult & $4.03 c$ & 3.34b & $2.86 \mathrm{~d}$ & $3.05 a$ & 2.95ab & $2.68 \mathrm{c}$ \\
\hline
\end{tabular}

Table (4) : Internode length $(\mathrm{cm})$ of seedlings with different development stage.

\begin{tabular}{|c|c|c|c|c|c|c|c|}
\hline \multicolumn{3}{|c|}{ Season 2009 } & \multicolumn{5}{c|}{ Season 2010 } \\
\hline & Terminal & Mid. & Basal & & Terminal & Mid. & Basal \\
\hline Juvenile & $1.77 \mathrm{~b}$ & - & $1.52 \mathrm{~b}$ & Juvenile & $2.18 \mathrm{a}-\mathrm{c}$ & $2.02 \mathrm{bc}$ & $1.63 \mathrm{~d}$ \\
\hline Transmission & $2.32 \mathrm{a}$ & - & $1.46 \mathrm{~b}$ & Transmission & $2.34 \mathrm{ab}$ & $2.35 \mathrm{ab}$ & $1.86 \mathrm{~cd}$ \\
\hline Adult & $2.37 \mathrm{a}$ & $2.19 \mathrm{a}$ & $1.49 \mathrm{~b}$ & Adult & $2.40 \mathrm{a}$ & $2.47 \mathrm{a}$ & $1.92 \mathrm{~cd}$ \\
\hline
\end{tabular}

olive seedlings was associated with an increase in the internode length.

\subsection{Leaf anatomy}

In the transverse section, thickness of the upper mesophyll was higher for the adult leaves than the juvenile leaves as shown in Figs. (1 and 2) the percentage of leaf thickness occupied by the two mesophyll tissues were quite different between the two leaf types.

In the juvenile leaves the adaxial mesopyll occupied ( $36.38 \%$ of the seeding tissue and $28.26 \%$ of Koroneiki tissue ) while, the upper 


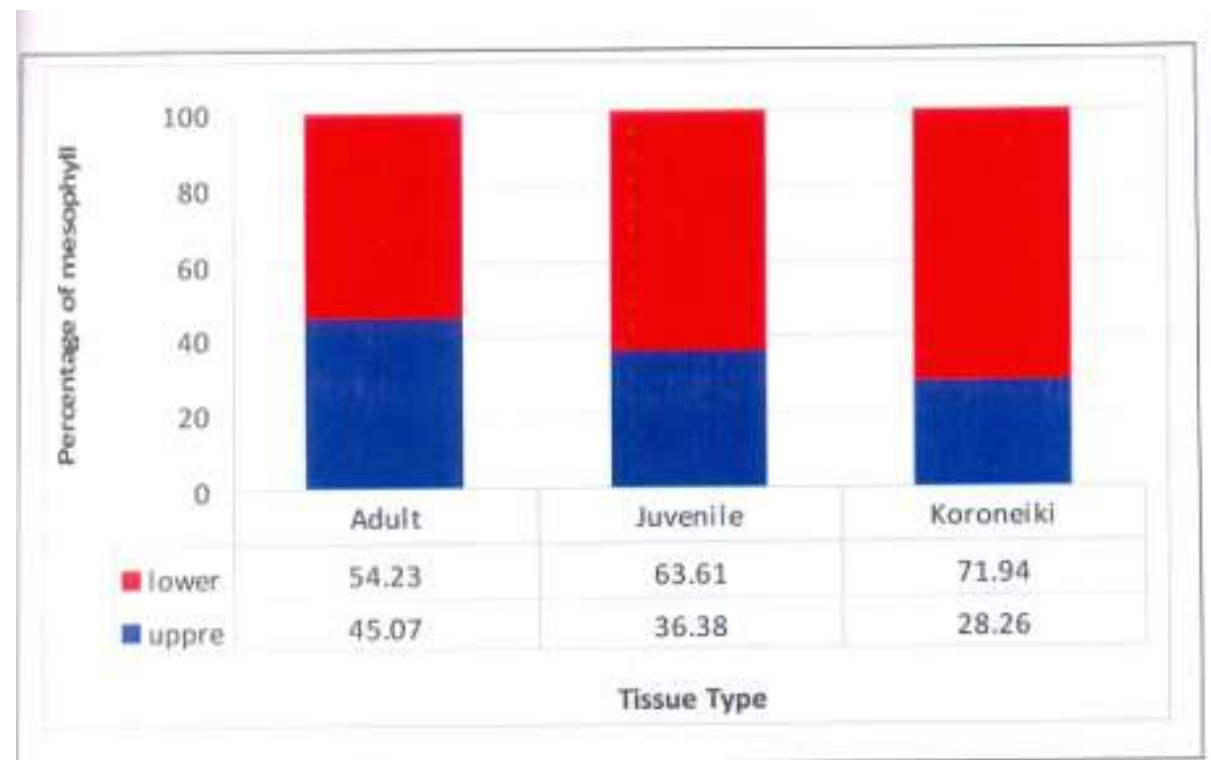

Fig. (1): Thickness of upper and lower mesophyll component in juvenile and adult seedlings compared to Koroneiki cutting.
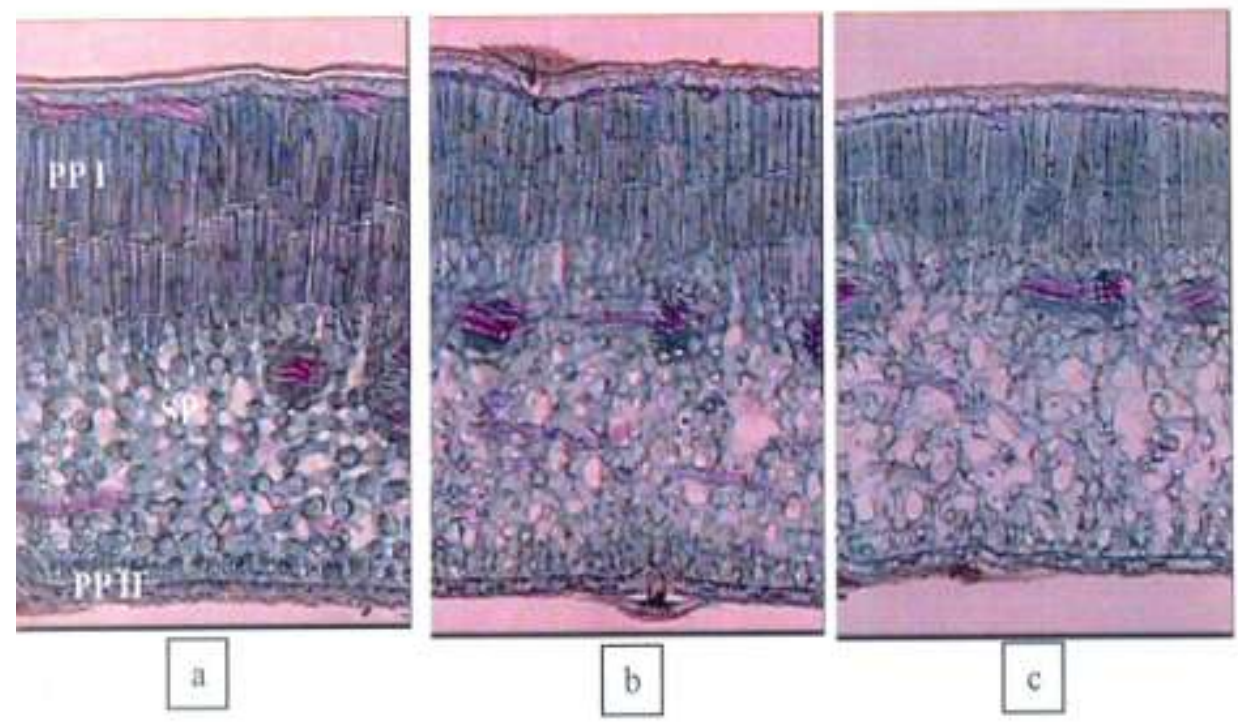

Fig. (2): Sections of olive leaves with different development status. a (Adult seedlings) b (Juven seedlings) c (Juvenile Koroneiki). Palisade parenchyma (PPI) palisade parenchy (PPII), spongy parenchyma (SP). 
mesophyll occupied $45.07 \%$ in the adult leaves. One of the major anatomical differences between adult and juvenile leaves was the layer of organized cells adjusted to the adaxial epidermis (palisade parenchyma PPII) which was present only in the adult leaves. This layer was reported in pervious studies on adult leaves (Chartzoulakis et al., 1999 and Bosabalidis and Kofidis 2002).

The spongy parenchyma was different in both types of leaves, in all cases it showed large intercelluer spaces as well as vascular bundles, the degree of compactness of the spongy mesophyll varied greatly among both type of leaves, but in adult leaves it tended to be less compact than in juvenile leaves.

From the obtained results it can be concluded that, the morphological and anatomical parameters may be used as markers of phase change in olive seedling, which will help in the selection of new lines which begin fruiting in short period.

\section{REFERENCES}

Ahmed F. F. and Morsy M. H. (1999). A new method for measuring leaf area in different fruit species. Mini. J. Agric. Res. \& Develop., 19: 97-105.

Allsopp A. (1967). Heteroblastic development in vascular plants. Adv. Morphog. 6:127-171.

Baldini E., Facini O., Nerozzi F., Rossi F. and Rotondi A. (1997). Leaf characteristics and optical properties of different woody species. Trees 12:73-81.

Basheer-Salimia, R., Patakas, A., Noitsakis, V., Bosabalidis, A. and Vasilakakis, M. (2004). Changes of morphological and physiological markers induced by growth phases in leaves of olive tree (Olea europaea L.). J. Biolog. Res. 2: $105-114$.

Bosabalidis A.M. and Kofidis G. (2002). Comparative effects of drought stress on leaf anatomy of two olive cultivars. Plant. Sci., 163: 375-9.

Chartzoulakis K., Patakas A. and. Bosabalidis A. M. (1999). Changes in water relations, photosynthesis and leaf anatomy induced by intermittent drought in two olive cultivars. Environ. Exper. Bot. 42 (2): 113-120.

Duncan D. B. (1955). "Multiple Range and Multiple F-Tests." Biometrics, 11: 1-42.

Freed R., Eisensmith S.P., Goetz S., Reicosky D., Smail V.M. and Wollberg P. (1990) MSTAT-C A Microcomputer Program for the Design, Management and Analysis of Agronomic Research Experiments Michigan State University.
Hackett W.P. (1985). Juvenility, maturation, and rejuvenility in woody plants, Hort. Rev.7: 109-155.

Hackett W. P. and Murray J. R. (1993). "Maturation and Rejuvenation in Woody Species," In: M. R. Ahuja, Ed., Micropropagation of Woody Plants, Kluwer Academics Publishers, Dordrecht, pp. 93105.

Jones C. S. (1999). An essay on juvenility, phase change, and heteroblasty in seed plants. Int. J. Plant Sci. 160 (6): s105-s111.

Kiran A.I., Rodríguez P., Ariza C., Barranco D., Rallo L., de la Rosa R. and León L. (2008). Seedling height as a pre-selection criteria for short juvenile period in olive seedling. Acta Hort. 791:61-64.

Lavee S., Avidan N., Haskal A. and Ogrodovich A. (1996). Juvenility period reduction in olive seedlings: a tool for enhancement of breeding. Olivae 60:33-41.

Leon L., De la Rosa R., Barranco D. and Rallo L. (2007).Breeding for early bearing in olive. Hort Science 42 (3):499-502.

Leopold A.C. and Kriedemann P.E. (1975). Plant growth and development. McGraw-Hill Book Co., New York.

Ligeng C., Keling C. and Guangyan Z. (1995). Genetic study and artificial regulation of juvenile period of citrus seedling. Acta Hort., 403:205-210.

Moreno-Alías I., León L., de la Rosa R. and Rapoport H. F. (2009). Morphological and anatomical evaluation of adult and juvenile leaves of olive plants. Trees - Structure and Function 23, (1):181187.

Murray J. R., Smith A. G. and Hackett W. P. (1994). Differential dihydroflavonol reductase transcription and anthocyanin pigmentation in the juvenile and mature phases of ivy (Hedera helix L.) Planta 194: 102-109.

Poethig, R. S. (1990). Phase change and the regulation of shoot morphogenesis in plants. Science 250: 923-930.

Pritsa T. S., Voyiatzis D. G., Voyiatzi C. J. and Sotiriou M. S. (2003). Evaluation of vegetative growth traits and their relation to time to first flowering of olive seedlings. Aust. J. Agric. Res.54 (4): 371 - 376.

Santos-Antunes F., Leon L., de la Rosa R., Alvarado J., Mohedo A., Trujillo I., and Rallo L. (2005). The length of the juvenile period in olive as influenced by vigor of the 
seedlings and the precocity of the parents, HortScience. 40 (5): 1213-1215.

Snedecor G. W. and Chochran W. G. (1980). Statistical Methods, Seventh Edition, Ames: Iowa State University Press.
Way R.D. (1971). Hastening the fruiting of apple seedlings. J. Am. Soc. Hort. Sci. 96: 384389. Zimmerman, R. H. (1972). "Juvenility and flowering in woody plants: A Review. HortScience.7 (5): 447-455.

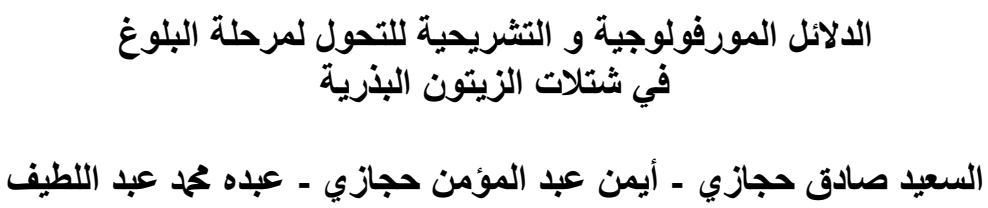

$$
\text { قسم الفاكهة ـ كلية الزر اعة ـ جامعة القاهرة - مصر }
$$

أجريت هذه الدر اسة خلال موسمي 2009 و 2010 بهدف تحديد دلائل التحول لمرحلة البلوغ في شتلات الزيتون البذرية. أجريت الدر است علي مجمو عة من شتلات الزيتون البذرية الناتجة من التلقيح المفتوح للصنف كروناكي و قد تم تقدير

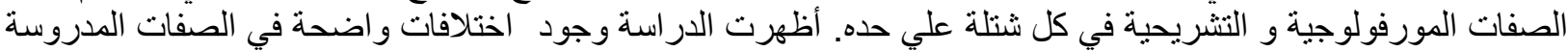

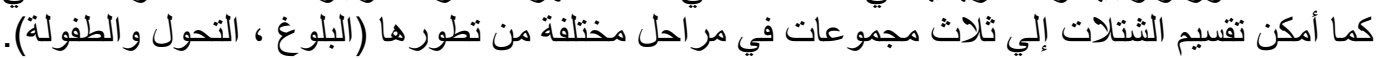

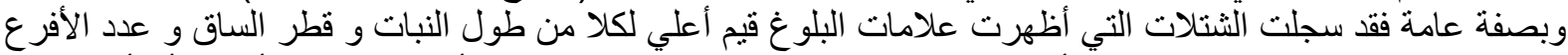

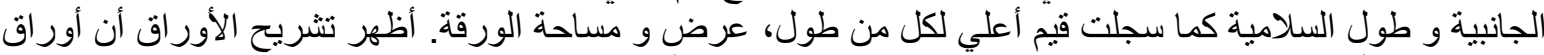

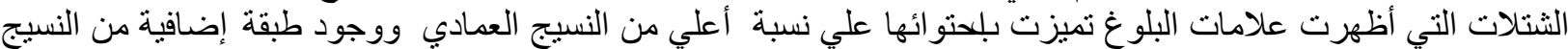
العمادي ملاصقة للبشرة السفلية . و هذه الخصائص يمكن أن تستعمل كدلائل بسيطة لانتخاب الثتلات التي تتميز بقصر فترة فئنة

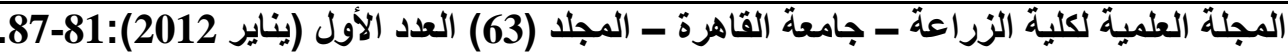

